MSCRA

3,2

98

Received 30 July 2020

Revised 22 September 2020

29 December 2020

24 January 2021

1 February 2021

Accepted 2 February 2021

\title{
Sustainable management of agriculture products value chain in responses to climate change for South-Eastern coast of Bangladesh
}

\author{
Prabal Barua and Syed Hafizur Rahman \\ Environmental Sciences, Faculty of Mathematical and Physical Sciences, \\ Jahangirnagar University, Dhaka, Bangladesh, and \\ Maitri Barua \\ Chattogram Veterinary and Animal Sciences University, \\ Chattogram, Bangladesh
}

\begin{abstract}
Purpose - This paper is designed to assess the sustainable value chain approaches for marketing channel development opportunities for agricultural products in coastal Bangladesh to combat climate change through an approach of community-based adaptation options.

Design/methodology/approach - The study was designed to select the potential value chain candidate and to analyze and establish a value chain map to benefit the crop farmers. In this connection, the resources of the whole context were evaluated. The approach uses few tools to generate three outputs, the last of which are the final list of value chains selected for in-depth assessment to design interventions as community-based adaptation practices of the study to combat climate change in the study areas.

Findings - The study demonstrated that the difference in the institutional circumstances of the end markets of the agriculture products is connected to the different categories of harmonization and control of the facilitating environment throughout the supply chains. National and local networks improve the value chain in terms of the value addition of the agriculture products, technology improvement, market access and profitability of the products. Strengthening the weak financial structure, focus more on formal financial systems and resolving sociocultural and climate change-induced hazard concerns are the major concerns on the development of value chains in the countries. Apparently, guarantee for good governance, checking illegal and unregulated market contexts, proper mitigation measures to climate change are some paramount important issues for the sustainable management of livelihood, yield, income and development.

Practical implications - All kinds of stakeholders of the agriculture product value chain should focus on competitiveness and productivity and look for and exploit multiple ways to add value once initial success has been attained with a single deal. Ensuring sustainability within the value chains is an important feature to cater to the challenges and changing demands of the age.

Originality/value - The study will help to established a sustainable value chain approach in response to climate change, which process will help to existent opportunities for firms to manage the issue of climate risk by codeveloping and employing adaptation options that may be more preferred or accepted by consumers across the entire chain for the sustainable management of livelihood, yield, income and development.
\end{abstract}

Keywords Sustainability, Climate change, Adaptation, Value chain, Agriculture crops Paper type Research paper

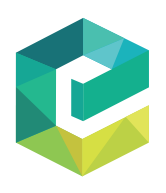

Modern Supply Chain Research and Applications Vol. 3 No. 2, 2021 pp. $98-126$ Emerald Publishing Limited 2631-3871

DOI 10.1108/MSCRA-07-2020-0020
(C) Prabal Barua, Syed Hafizur Rahman and Maitri Barua. Published in Modern Supply Chain Research and Applications. Published by Emerald Publishing Limited. This article is published under the Creative Commons Attribution (CC BY 4.0) license. Anyone may reproduce, distribute, translate and create derivative works of this article (for both commercial and non-commercial purposes), subject to full attribution to the original publication and authors. The full terms of this license may be seen at http:// creativecommons.org/licences/by/4.0/legalcode 


\section{Introduction}

The climate of Bangladesh is uneven and it is becoming more impulsive every year and these consequences are observed as the more changeable precipitation, more extreme weather events and increasing sea level are already happening in Bangladesh and will continue to intensify. Bangladesh is most vulnerable to climate change hazards because of its low-lying topography; its geographical location that makes it horizontally vulnerable to cyclones and strong tidal surges; its high population density and urban-rural poverty, and a market based on agriculture products, Bangladesh experiences recurrent events of tremendous climatic hazards, often in the appearance of floods, droughts, coastal and riverbank erosion, salinity intrusion, cyclonic storm surges and water logging that make the community people's living situation more vulnerable (Barua et al., 2017, 2020).

Climate change vulnerability is ambitious by a series of physical, social, economic and environmental consequences and/or processes that accelerate the vulnerability of a community/system to the collision climatic hazards. However, affect to diverge spatially and over time, connotation that not all communities are uniformly vulnerable to climate change hazards (Fraser et al., 2011; Füssel, 2010; O’Brien, 2010). For diminishing the negative livelihood influences, a place and context-specific estimation is desired for measuring vulnerability to facilitate appropriate targeting adaptation policies and strategies at local, national and international stages (Barua and Rahman, 2019; Alam et al., 2016; Below et al., 2012).

The value chain of agricultural products engages a sequence of value-adding actions that carry products from the farm to the final consumer (Miller and da Silva, 2007). Value chain connection together with input providers, farmers, processors, retailers, and consumers that facilitate the effectual execution of the marketplace. By recognizing the role of the value chain reduction of the poverty level and approaches of sustainable food security in the least developed countries, governments and development agencies have increasingly focused on the development of the sustainable approach of the value chain for agricultural products through providing the inputs, investing wealth, and additional services that contribute for their development. At the same moment, there is an increasing awareness that the climate change effects intimidate the sustainability of these agriculture product value chains, potentially affecting the profits and livelihoods of different actors involved. Progress of agricultural product value chains must therefore be climate resilient, with different actors along the chain vigorously involved in managing climate risks. It is argued that a sustainable approach of the value chain is functional in exploring climate change-induced vulnerability, as it looks beyond production and fosters a supplementary systemic process for vulnerability management (Dekens and Fredrick, 2014).

Climate sensitive sustainable value chain can be comparatively straightforward; for example, the value chain process of vegetable and fish products involved the concerned marginalized rural producers, intermediates and processors/packaging houses, wholesalers and retailers. A sustainable value chain can be enormously multifaceted, for instance, in the case of a passenger car or an individual computer or a footwear or garment factory, where the producers in various nations across the globe work mutually together. The approach of sustainable value chain was taken into account by the founders both as an opportunity and a risk. The risk lies in the fact that developing nations' producers could not be incorporated into universal markets if they could not convene the necessities of value chain lead firms concerning cost, quality, certification, quantity, and appropriate delivery time. The probability lies in the truth that linking developing nation's producers to the global market could be easier if the international funding organizations manage to erect a direct association with a value chain lead firm.

Although Bangladesh is gifted with productive agricultural land and a positive climate for the various types of agriculture crop production, current trends of climate change brought this country to the inventory of the most susceptible one. Allowing for its potency,
Management

of agriculture products value chain 
MSCRA

3,2

100

Bangladesh Government has given much importance to the agricultural products and agrobased sector industries in the country.

A value chain approach to climate adaptation may therefore present opportunities for firms to manage the issue of climate risk by codeveloping and implementing adaptation options that may be more desired or accepted by consumers across the whole chain. Although climate change adaptation can occur in isolation at specific nodes of the chain, there may be greater benefits if all chain members understand how consumers may respond to and value each adaptation strategy. This is no different from widely acknowledged approaches to developing sustainable solutions to climate change, whereby the involvement of society at all scales, including government, commerce and industry and the wider public, is required (Lorenzoni et al., 2007; Camacho et al., 2015). Achieving these benefits requires that firms in the value chain collaborate to ensure that consumer-driven responses to climate change are complementary to each other's business strategies, and enhance business-to-business relationships on the vegetable and fish sectors in an efficient manner.

Usually, rural inhabitants in Bangladesh relied on the resources hauled out from natural sources like forests, wetlands, rivers and sea for their livelihood. Nowadays, even the livelihood of the poor, especially those having limited or no access to land is still dependent on these resources. However, the increase in population means more extraction of these resources. Hence, relying only on natural resources for a livelihood has become complicated for the resource extractors. At the same moment, due to excess resource extraction, the sources are not being replenished naturally, resulting in an adverse natural phenomenon and climactic effects. Furthermore, coastal communities are more vulnerable to lose out in the marketing chain as they usually suffer more from lack of credit accessibility in comparison to the similar communities living in the vicinity of cities where pro-poor, microcredit activities by Non-Government Organizations (NGOs) are available. Under this circumstance, alternative livelihood options are required for these poor people, which will reduce their dependence on natural resources and improve their livelihoods through increased income.

Although Bangladesh is demonstrating the story of the turndown of the rate of rural poverty during the current times, coupled with the growth of the nonfarm segment, a sluggish agriculture output (and also low productivity), and low growth in the salary, although heartening learning about the latent of the sector in the account of job employment, has however not established the capability on the sector to give increasing salaries and earning to the workers (Uddin and Akhter, 2019). There is thus an imperative requirement for observing more intimately the potentialities of promoting rural livelihoods of community people in the explicit region like vulnerable coastal areas of Bangladesh. The present study may thus be noticed within the over the superior picture of poverty, livelihoods, and employment opportunity for coastal communities of Bangladesh.

One way to summarize the standard flow of the value chain analysis process is to start at the end-market to find the popular process of rewarding pro-poor supply chains and then work backward in the course of the sustainable process of the value chain to reach the target people of the selected value chains, wherever they may be. The process is summarized below in Figure 1:

Figure 1.

Normal value chain process

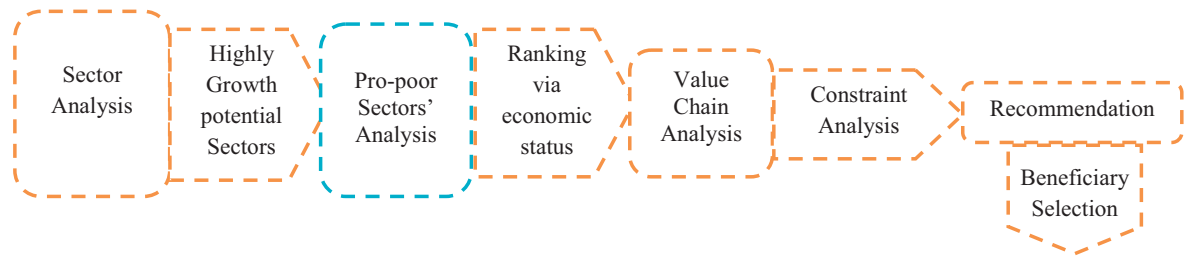


However, this process is not perfectly suited to value chain analysis (VCA) for this study because of following reasons: (1) The target people of the study areas have already been selected, limited to specific areas; (2) They live in coastal areas, which due to infrastructural challenges and special institutional constraints indicate that identified end-market is often completely immaterial to communities current economic situation; (3) The selected value chain must be existing realities related, which may not be the case if a normal VCA based on economic criteria alone is used. The process is summarized below in Figure 2.

\section{Climate change and agriculture industry of Bangladesh: uncertainties and implications}

Bangladesh is gifted with a favorable climate and soil circumstances for the different crops production all through the year. The agriculture sector is the economic heart for Bangladesh because of the involvement of the mass population for their livelihood through food production in the crop field and it is also nation's food security. But nowadays, coastal inhabitants have been experiencing lower crop productivity and fewer cropping intensities due to various climatic vulnerabilities, such as salinity intrusion problem damaging the coastal area through reduction of crop production and water insecurity. It is found that about $53 \%$ of coastal area are affected by different degrees of salinity, and among them light 0.29 , moderate 0.43 and high 0.12 million hectares land salinization involving a of cost 586.75 million US\$ per year. Within three decades, sediment level increased in the coastal area up to $21 \%$ in this region (Ahsan and Brandt, 2015; Ali and Hossain, 2019; Barua et al., 2017).

Bangladesh constantly is losing agricultural cropland because of population growth, increasing urbanization, industrial activities and salinization crisis in the sediments. The changing pattern of rainfall could have had significant influents during the sowing and harvesting periods of crops. The farming process strongly relies on the scheduled period of monsoon season arrival and its raining pattern (Hasan et al., 2009, 2017; Anik and Khan, 2012). The exhaustion of the organic matter of the sediments due to ground water and sediments dilapidation is increasing in Bangladesh that might muscularly impact agriculture in the country (Ali et al., 1997, Hossain, 2001; Rahman and Parkinson, 2007). A significant decrease in crop yield due to salinity and tidal has already been recorded in the coastal area during the dry summer season. Salinity causes unfavorable environmental and hydrological circumstances that restrict normal production of agriculture crops around the year in the coastal areas (Rahman et al., 2014; Clarke et al., 2015; Zahangeer et al., 2017). Coastal Bangladesh used to contribute to the $20 \%$ of the total production of rice in Bangladesh (Bala and Hossain, 2010). Shelley et al. (2014) mentioned that rate of high price increases and rice prices rapidly going up during the period 2005-2008 inceased the poverty rate to $8.5 \%$ in Bangladesh. Stability would be multidimensional approaches that will come from every side of government, NGO and the local community.

Coastal inhabitants of Bangladesh depend on fisheries sector are suffering enormously through multi dimensional problem because of climate change (Barua et al., 2020). Livelihood of the fishermen impacted by numbers of climate induced hazards like cyclones, floods and rising sea levels and their fishing actions are affected mainly due to cyclones. Barua et al. (2020) found the lessening of the days of fishing by fishermen in Bangladesh significantly

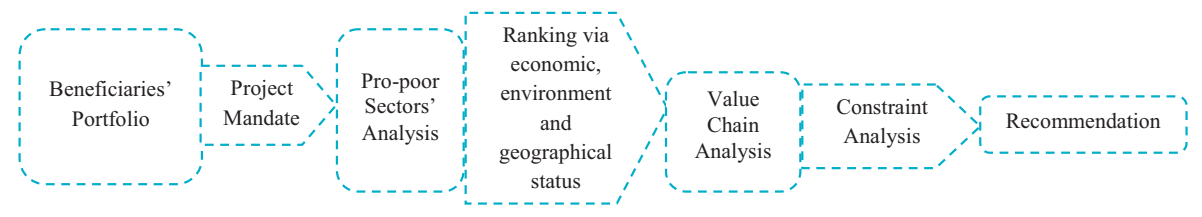

Management of agriculture products value chain 
MSCRA

3,2

102

increased due to cyclones, depression and larger vacillation in the production of marine and coastal fisheries because of the present scenario of changing climate and climate variability. These impacts, taken jointly, may additionally augment the vulnerability of sustainable livelihood for the coastal fisherfolks devoid of adaptation practices in response of the changing climate.

Mahashin and Roy (2017) recommended climate-smart agriculture (CSA) development in coastal Bangladesh, which is a process that supports the guide actions required to transform and introduce new types of agricultural systems to significantly support the development and secure food security to adapt to the changing climate. This practice and technologies provided opportunities for addressing challenges of changing climate change and for increasing the growth and development of the agriculture industries of Bangladesh. For benefiting the poor people for community-based adaptation in response to climate change, this study revealed marketable and nonmarketable resources in the target areas, their product value chains, actors, and their roles in governing value chains and the probable way of solution. Poor agricultural cultivators who are living in coastal areas have less access to the market for many reasons, which entails the absence of accessibility for credit and technology in Bangladesh. This research seeks to address the following research objectives: (1) Mapping the vegetable product value chain in the investigative areas, (2) SWOT analysis of vegetable value chain and (3) Constraints analysis of vegetable value chain in responses to climate change. The authors conducted the study to fulfill the aim of the following objectives: (1) Identify marketable and nonmarketable resources, primary and secondary markets, landing centers, network of actors that creates unequal income distribution in four coastal districts, (2) Documentation of marketable and nonmarketable resources in climate change affected project sites of four coastal districts and (3) Development of the value chain and marketing with existing and proposed market flow design, including the network of actors and their specific roles.

\section{Materials and methods}

\subsection{Study area}

There are two coastal districts, Chittagong and Cox's Bazar, situated in the south-eastern part of the country. The present study was operated in the four subdistricts under the two districts of the south-eastern coastal area of Bangladesh. Banshkhali and Anwara subdistricts are located under the Chittagong district, and Teknaf, as well as Maheskhali subdistricts, are situated under Cox's Bazar district. Here, Maheskhali is known as an island and a hard-toreach place because of its geographical location (Table 1). The study was conducted form January 2018 to March 2018.

\subsection{Approach of the value chain selection}

The study was designed to select the potential value chain of agriculture products like vegetables and fisheries products, which could analyze and establish a value chain map to benefit the project participants. In this connection, the resources of the whole context were

Table 1.

Geographic location of the study areas

\begin{tabular}{llll}
\hline District & Subdistrict & Union & Main market \\
\hline Chittagong & Banshkhali & Khankhanabad & Premasia \\
Chittagong & Anwara & Raypur & Kuruskul \\
Cox's Bazar & Teknaf & Baharchara & Lambarhat \\
Cox's Bazar & Maheskhali & Saplapur & Saplahat \\
\hline
\end{tabular}


evaluated. The authors use a few tools to produce three outputs from the previous final value chain lists chosen for the in-depth appraisal to design interventions of the research study.

\subsection{Data collection and analysis}

The authors applied the statistical analysis for sample size determination of household survey through the application of formula by Islam (2014), which is as follows:

$$
\text { Formula, } n_{0}=\left(\frac{z^{2} p q}{d^{2}}\right)
$$

where $n_{0}=$ desire sample size, $z=$ standard normal deviate usually set at 1.96 , which corresponds to the $95 \%$ confidence level $(z=1.96), p=$ assumes proportion in the target population estimated to have a particular characteristic $(p=0.5), q=$ proportion of the estimation of population $(q=1-p), d=$ allowable maximum error in estimating a population proportion $(d=0.05)$.

Moreover, the simple random sampling technique was adopted for successfully operating 385 questionnaires at a household level of the displaced people (Table 1). Considering the representative sample size, the authors have distributed those samples on the statistical way with the help of the following formula;

$$
\text { Random sampling, } N_{j}=\left(\frac{n}{N}\right) N_{i}
$$

where, $N_{j}=$ represents the sample size, $N=$ total population size, $\left(N=n_{i}+n_{i i}+n_{i i i}+\ldots \ldots+\right.$ $\left.n_{n}\right), N_{i}=$ population size of study area, $n=$ desired sample size.

The authors analyzed the survey information of households through the analysis of value chain, problem and opportunities perspectives. The study relied more on secondary information that was collected from value chain actors like retailers, wholesalers and collectors required for the analysis of the last end market (Singh and Mishra, 2013; Trienekens, 2011).

The authors developed the mapping of the value chain for illustrating the conduit flow of the crop products from the conception stage to the production stage and finally to the final consumers through the traders. It identified the actors and support service providers, their roles and interactions around the process of the value chain, and their performances. After mapping the selected value chains of different regions, the opportunities to include the target beneficiaries for conserving the natural resources in the study areas were identified. A comprehensive, cost-benefit analysis has been done on each and every specific product in the selected value chains on specific locations. This cost benefit analysis revealed the strengths and weaknesses of every subsector to be worked on strategic opportunities.

\section{Results and discussion}

Although Bangladesh is endowed with fertile lands and favorable climate for the production of various agricultural products, recent trends of climate change brought this country into the list of the most vulnerable ones. Usually, rural inhabitants in Bangladesh relied on the resources hauled out from natural sources like forests, wetlands, rivers, and sea for their livelihood. Nowadays, even the livelihood of the poor, especially those having limited or no access to land is still dependent on these resources. However, the increase in population means more extraction of these resources. Hence, relying only on natural resources for a livelihood has become complicated for the resource extractors. At the same time, due to excessive resource extraction, the sources are not being replenished naturally, resulting in an adverse natural phenomenon and climactic effects. Furthermore, coastal communities are more vulnerable to lose out in the marketing chain of vegetables and culture and capture 
MSCRA

3,2

\section{4}

fisheries as they usually suffer more from lack of access to credit sources in comparison to the similar communities living in the surrounding area of urban cities. Under the circumstance, alternative livelihood options are required for these poor people, which will reduce their dependence on natural resources, as well as improve their livelihoods through increased income.

\subsection{Community profile of the studied areas}

There are 420 households that were covered in the interview and among the respondents, the sample size of every study area is divided based on populations (Table 2).

Among the activities, most of the beneficiaries have paddy cropping patterns in the different seasons with different seeds, which is about $43 \%$ on average, and Anwara subdistrict dominates with paddy cropping with $63 \%$ of their activities. The fisheries sector covers about $36 \%$, and vegetables are practiced by $9 \%$ of participants. It was seen that in the vegetable sector, there is a huge opportunity to increase their productivity and income. Among the study area population, $29.8 \%$ of inhabitants from Maheskhali stated that they were regularly practicing the paddy crops as like other regions of Bangladesh. As most of the participants do not possess enough land apart from their small homestead or pond dike, $17.22 \%$ of people cultivate fish in ponds, $15.89 \%$ people engage in coastal fishing and $12.58 \%$ cultivate vegetables on as mall scale or medium scale. In Teknaf, about $30 \%$ of people stated they were involved in cultivating paddy crops as major earning sources. About $22 \%$ of people earn from fish capture that is a seasonal profession, $15.38 \%$ people mentioned cattle rearing, $14.29 \%$ of people practice vegetable cultivation as their main income-earning option, and $10.44 \%$ of people have fish cultivation. A minor percentage of people catch shrimp and prawn postlarvae (PL), which is a threat to biodiversity.

In Anwara subdistrict, $63.54 \%$ of people were seen to earn from paddy culture, whereas $12.5 \%$ of people mentioned catching fish, $10.42 \%$ of people mentioned cattle rearing and only $4.17 \%$ of people have major income from fish cultivation. In Banskhali, nearly $50 \%$ people was seen to earn from paddy culture whereas $38.89 \%$ people mentioned as catching fish and $5.56 \%$ people mentioned about vegetable cultivation and remaining $5.55 \%$ people has major income other activities like nut cultivation, etc.

\subsection{Marketable vs nonmarketable resources and value chain selection for study}

Islam (2003) stated that the geographical location and the climatic condition of Bangladesh had made her coastal areas a highly productive region in the world for agriculture production. About 20 million coastal inhabitants' are representatives of the poorest and most marginalized groups of the nation; $20 \%$ of people directly rely on the coastal and marine resources for maintaining their livelihood. They live exclusively on fishing, either as boat owners or as laborers, processing and marketing of agricultural products. The market for several of these products is promising, but the people involved early in the production chain, in fishing, primary processing and local trading, add little value, and therefore, can make a little profit. The low returns experienced by these groups are partly related to poor product

Table 2.

Determination of sample size among three study areas

\begin{tabular}{lcr}
\hline Sample area & Total Population BBS (2011) & Sample size \\
\hline Banshkhali & $4,31,162$ & 160 \\
Anwara & $2,62,703$ & 80 \\
Maheskhali & $3,21,000$ & 100 \\
Teknaf & $2,64,389$ & 80 \\
Total & $12,79,254$ & 420 \\
\hline
\end{tabular}


quality and partly to lack of bargaining power in the marketing networks. In this study, the selected beneficiaries are experienced with some common resources that vary from location to location based on the suitability of the context. The authors found some important candidates as marketable resources that are listed below (Table 3);

Vegetables in much of Asia and the Pacific region are grown by small-scale farmers who are unorganized and scattered in different locations (Lusine et al., 2007), and this is also useful for Bangladesh. Absorption of the crop production is significant because low production could impact all the actors in the agribusiness sectors. Low crop production is the consequence of limited access to inputs like irrigation, seeds, fertilizers, and credit, poor cultural practices, poor soil and low levels of management skills (Cook and Iliopoulos, 1999). Vegetable processing, trading, sorting, grading and marketing require some vital support of integrated value chain management system. Because of its perishable nature and more consistent application of quality standards, the organizations engaged in the trades of these horticultural commodities have to face enormous quality problems. The value chain for vegetable crops begins upstream with the production of goods by individual farmers, cooperatives or farming corporations and broadens downstream as the product is transformed or repacked to be sold either through retailers or be served in restaurants, where the final consumer is reached (Regmi and Bhandari, 2013).

The respondents were asked about their major commercial resources and they answered that where very low production species were considered as nonmarketable resources that are mainly used for home consumption were priority based. But, the marketable resources are well practiced in the areas, which demands market development for the benefit of the poor. Fruits are a high-value crop, and farmers were reluctant to go for bulk production due to risk and natural threats. Paddy is a crop that is consumed only in the local market and because of being a unique crop, the value chain of the paddy crops was considered as not sustainable. Two resources were selected as the best to develop the value chain among the areas, which are vegetables and fish.

\subsection{Value chain study for vegetable and fish sector}

The value chain elaborates the filled series of actions, which are requisites to carry out the production of goods from the beginning, through the diverse stages of the production, release to final consumers of the products (Kaplinsky and Morris, 2000). In reality, the value chain tends to be extended with an entire series of actions within every link and links among the diverse value chains. Despite the intrinsic complexity, analysis of the product value chain can intensify exploration into the disjuncture between lofty stages of economic addition into national and planetary product markets and the degree to which countries and people really add from such incorporation (Jacinto, 2004).

In Banskhali, Teknaf, Maheskhali and Anwara subdistricts, the vegetable and fish producers were selling the products in the nearby market and the fishery ghat (in case of

\begin{tabular}{lll}
\hline Areas & Marketable resources & Nonmarketable resources \\
\hline Banskhali & $\begin{array}{l}\text { Paddy, Vegetables, Cultured Fish, Captured Fish, } \\
\text { Fruits, Chili, pulse }\end{array}$ & $\begin{array}{l}\text { Poultry, Honey, Wheat, Potato, Cattle, } \\
\text { Shrimp, Corn } \\
\text { Teknaf }\end{array}$ \\
$\begin{array}{l}\text { Paddy, Vegetables, Captured fish, Cultured Fish, } \\
\text { Crab }\end{array}$ & $\begin{array}{l}\text { Peanut, Corn, Jute, Poultry, Cattle, Honey } \\
\text { Paheskhali }\end{array}$ \\
Paddy, Vegetables, Captured fish, Cultured fish, & Shrimp, poultry, Honey, Wheat, Potato \\
& $\begin{array}{l}\text { Pulse, Chili, Nut } \\
\text { Paddy, Vegetable, Cultured Fish, Captured Fish, } \\
\text { Shrimp }\end{array}$ & Poultry, Cattle, Honey, Jute, Crab, Corn
\end{tabular}

Management of agriculture products value chain 
MSCRA

3,2

106 captured fish). In a few belongings, the agricultural crop producers that were having many productions and huge amounts of catch, started to bring their products to wholesale marketing in nearby markets of urban markets. During the peak season of agricultural product marketing, sometimes the producers were observed to go to district markets to vend their fish and vegetables that having the highest quality price. Maximum vegetables and fish producers usually recorded to sell crop products to beparies at the fish landing station and bazaar points and to some extent, interdistrict aratdar and meting out plant and agencies.

\subsection{Value chain selection}

In traditional value chain strengthening programs, the value chains having good potentials and meeting with project mandates are selected, and then beneficiaries are selected to match with the value chain requirements. Hence, while developing the preliminary list of value chains, the authors recognized the commercial activities that the community people are currently engaged with, along with beneficiaries' resources, previous experience and expertise. That value chain that destructs forest and/or wetland directly will be ineligible for selection. Considering this fact, the authors had to eliminate the livestock-related value chains like cattle rearing. During this time, the community people either let their cattle and/or goat graze freely around or in the forest or they collect leaves from trees in the forest. Both these options are directly involved in the deterioration of forest resources.

\subsection{Potentiality estimation of selected sectors}

Among the studied areas, some features were identified as the potential for the culture of vegetables (Table 4) and for fish species (Table 5) according to the standard procedure without disturbing indigenous technologies. The potential issues are pointed below;

4.5.1 Value chain analysis for vegetable products. The vegetable growing areas in Bangladesh is about 0.358 million hectares. Besides, about 19.4 million homesteads cover about 0.45 million hectares of area for vegetable production. Production of vegetables increased from 1.79 to 3.00 million tons from 2005-06 to 2009-10. Among the vegetable crops, brinjal occupied the highest area (16.9\%), followed by radish $(8.4 \%)$, pumpkin $(6.8 \%)$, aroids

\begin{tabular}{|c|c|c|c|}
\hline Banskhali & Teknaf & Maheskhali & Anwara \\
\hline $\begin{array}{l}\text { (1) Homestead and } \\
\text { cultivable land } \\
\text { spaces are } \\
\text { available } \\
\text { (average } 58 \\
\text { decimal) } \\
\text { (2) High unmet } \\
\text { regional } \\
\text { demand } \\
\text { (3) Scopes for } \\
\text { potential } \\
\text { upgrade of } \\
\text { culture } \\
\text { practices, } \\
\text { postharvest } \\
\text { techniques } \\
\text { and trading } \\
\text { efficiency }\end{array}$ & $\begin{array}{l}\text { (1) Currently, } 30 \% \text { of } \\
\text { beneficiaries are } \\
\text { involved in the } \\
\text { value chain } \\
\text { (2) Beneficiaries have } \\
\text { cultivable land } \\
\text { (average } 59 \\
\text { decimal) } \\
\text { (3) Soil is very fertile } \\
\text { (4) Homestead spaces } \\
\text { are available } \\
\text { (5) High unmet } \\
\text { regional demand } \\
\text { (6) Scopes for potential } \\
\text { upgrade of culture } \\
\text { practices, } \\
\text { postharvest } \\
\text { techniques and } \\
\text { trading efficiency }\end{array}$ & $\begin{array}{l}\text { (1) Homestead and cultivable } \\
\text { spaces are available } \\
\text { (average } 49 \text { decimal) } \\
\text { (2) High unmet regional and } \\
\text { national demand } \\
\text { (3) Scopes for potential } \\
\text { upgrade of } \\
\text { culture practices, } \\
\text { postharvest techniques } \\
\text { and trading efficiency }\end{array}$ & $\begin{array}{l}\text { (1) Currently, } 25 \% \text { of } \\
\text { beneficiaries are } \\
\text { involved in the value } \\
\text { chain } \\
\text { (2) Beneficiaries have } \\
\text { cultivable land } \\
\text { (average } 42 \text { decimal) } \\
\text { (3) Homestead spaces are } \\
\text { available } \\
\text { (4) High unmet regional } \\
\text { demand } \\
\text { (5) Scopes for potential } \\
\text { upgrade of culture } \\
\text { practices, postharvest } \\
\text { techniques and trading } \\
\text { efficiency }\end{array}$ \\
\hline
\end{tabular}

Table 4.

Area wise potential outreach for vegetable production 
$(6.4 \%)$, tomato $(6.2 \%)$, and bean $(4.7 \%)$. Vegetables are grown all over Bangladesh, but the extent of cultivation varies from one region to another. Some crops have concentrated areas for production because of favorable agroecological conditions and better marketing facilities (Hooq et al., 2012).

Vegetable cultivation is not a very recent sector in the study areas; it was introduced by the local farmers themselves mainly for local consumption. In maximum areas, vegetables are the "survival crop" for the poor farmers and fishermen, but in the case of Shaplapur Union of Maheskhali subdistrict under Cox's Bazar district, the scenario is a bit different. They replaced commercial production of the paddy crop with the production of vegetables and fish. They are following the ditch and dike method to produce vegetables and fish. And in a very short time, they earned success. Now the products gained the market in city areas like Cox's Bazar, Chittagong, Dhaka and Barisal, etc. Most of the farmers are not aware of how best to treat saline soil, and thus, the productivity of vegetables is being hampered; also, households rarely use their homestead space to cultivate vegetables other than potato and chili. Thus, vegetable production is relatively low in the study areas. The cyclone had caused immense destroy the human life and properties in the coastal areas and left the soil in these areas highly saline, destroying crops and agricultural lands. But, in current times, the sediment of croplands, mostly recovered from this destruction and the production of different vegetables are started out again in various locations of the coastal areas. The vegetables that are grown (Table 6) in these regions include the followings;

The productivity of increasing vegetables production is now much higher than traditional crops in the study areas. However, the profit differs from site to site depending on soil conditions, climatic impacts, environmental concerns, etc. Thus, different vegetables were chosen to capitalize on the individual suitability of the vegetables to the respective sites. An average cost-benefit analysis of vegetables has given in Table 7. It can be seen from Table 7

\begin{tabular}{|c|c|c|c|}
\hline Banskhali & Maheskhali & Teknaf & Anwara \\
\hline $\begin{array}{l}\text { (1) More than } 90 \% \text { of } \\
\text { beneficiaries have a } \\
\text { pond of at least } 4.26 \\
\text { decimal } \\
\text { (2) High unmet regional } \\
\text { and demand } \\
\text { (3) Scopes for potential } \\
\text { upgrade of culture } \\
\text { practices, postharvest } \\
\text { techniques and } \\
\text { trading efficiency }\end{array}$ & $\begin{array}{l}\text { (1) Currently } 70 \% \text { of } \\
\text { beneficiaries have } \\
\text { a pond } \\
\text { (2) High unmet regional } \\
\text { and national demand } \\
\text { (3) Scopes for potential } \\
\text { upgrade of culture } \\
\text { practices, postharvest } \\
\text { techniques and } \\
\text { trading efficiency }\end{array}$ & $\begin{array}{l}\text { (1) Currently } 90 \% \text { of } \\
\text { beneficiaries have } \\
\text { a pond } \\
\text { (2) High unmet regional } \\
\text { and national demand } \\
\text { (3) Scopes for potential } \\
\text { upgrade of culture } \\
\text { practices, postharvest } \\
\text { techniques and } \\
\text { trading efficiency }\end{array}$ & $\begin{array}{l}\text { (1) Currently } 95 \% \text { of } \\
\text { beneficiaries have } \\
\text { a pond } \\
\text { (2) High unmet regional } \\
\text { and national demand } \\
\text { (3) Scopes for potential } \\
\text { upgrade of culture } \\
\text { practices, postharvest } \\
\text { techniques and } \\
\text { trading efficiency }\end{array}$ \\
\hline
\end{tabular}

Management of agriculture products value chain

\begin{tabular}{ll}
\hline Region & Crop \\
\hline Banskhali & $\begin{array}{l}\text { Potato, brinjal, bitter gourd, snake gourd, spinach, pumpkin, eggplant, okra, summer tomato, } \\
\text { cucumber, and chili }\end{array}$ \\
Maheskhali & $\begin{array}{l}\text { Cucumber, pumpkin, calabash, bitter gourd, snake gourd, eggplant, chili, kidney bean, tomato, } \\
\text { etc. }\end{array}$ \\
Teknaf & $\begin{array}{l}\text { Pumpkin, calabash, cucumber, citter gourd, snake gourd, eggplant, chili, kidney bean, tomato, } \\
\text { etc. }\end{array}$ \\
Anwara & $\begin{array}{l}\text { Brinjal, bitter gourd, snake gourd, Potato, spinach, pumpkin, eggplant, okra, summer tomato, production practiced in } \\
\text { cucumber, and chili }\end{array}$ \\
\hline
\end{tabular}


MSCRA

3,2

108

Table 7.

Average cost-benefit analysis (in BDT) of some species in the context

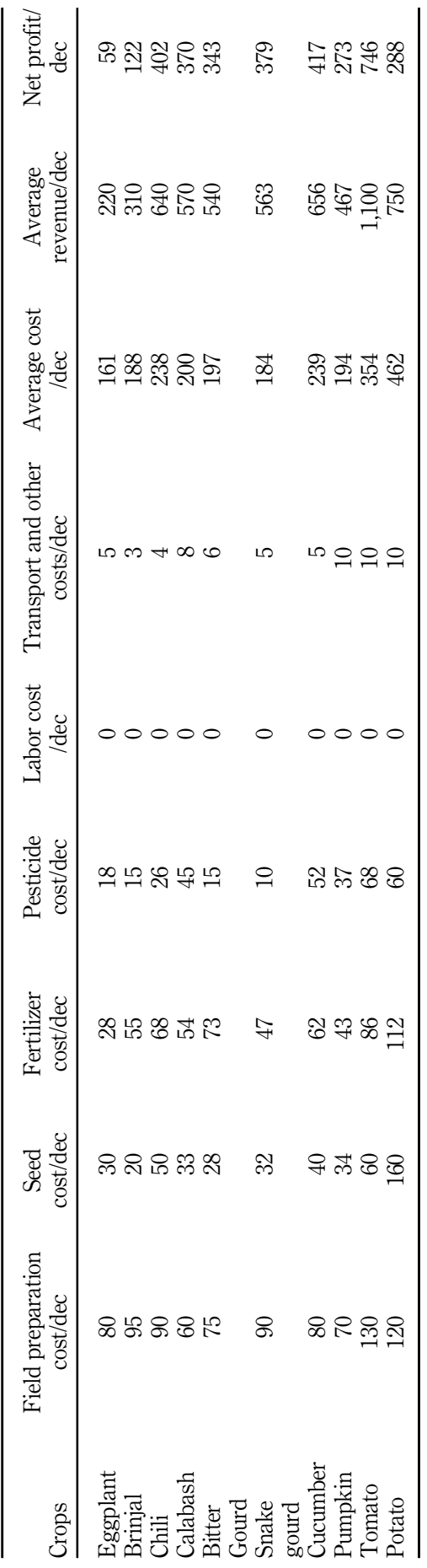


that per decimal, tomato production was most profitable, followed by cucumber, chili and snake gourd. However, per decimal production cost was lower for eggplant followed by brinjial and snake gourd.

Approximately all types of vegetables produced in the study areas are consumed locally, and there is even a breach in supply that is overflowing with vegetables being imported from the outside market of the study areas. The site-wise market analysis of vegetables in the contexts is given below in Table 8 .

Vegetables sold in these regions are almost completely used up for local consumption by households. In the study areas (Maheskhali and Anwara sub-districts) it was found to promote vegetables in the forward market apart from their local bazaar. The consumption pattern reveals that the average daily consumption composition is shaped by locally available vegetables. Rarely vegetables from distant villages reach these markets. The local consumption of vegetables largely depends on the supply and the price of vegetables, which is higher than the national level markets. Due to the perception that vegetables cannot be grown on saline soil, some areas do not have the practice of cultivating them.

The vegetable value chain in the study areas was mapped using information from the different study areas. The players in the vegetable supply chain consisted of producers, collectors or transporters, wholesalers, retailers, and hypermarkets or supermarkets. In the study areas, there are different types of input suppliers that are active and catering to the different kinds of vegetable cultivators, seasonal and commercial agro farms and marginal farmers. The marginal farmers mostly buy their inputs, mainly seeds or seedlings, from the local bazaar, mainly from the mobile vendors/sellers who sit on the floor of main bazaars. These input sellers generally sell quality seeds and seedlings also grown from unknown branded seeds. The input retailers, with their own establishments in the bazaars, tend to sell different kinds of inputs - seeds, fertilizers, and pesticides. These suppliers bought their products from the selected input dealers, and input suppliers have very little data on technical issues of using different inputs; however, they are interested in providing cultivation advice as a means to market their products better. Most farmers also tend to use their own seeds for certain vegetables, like potato, brinjal, lady's finger, etc. Figure 3 provides an indication of the involvement of different players through the production, processing, and selling of vegetable value chain in the study areas (Figure 3 ).

There are empty storage services, and an immediate requirement for financial need forces the farmers to sell the vegetables instantly after the time of collection from the cropland. They carry on head loads and make use of locally available small vans to transport the crop products into the local markets from crop fields. This was found from the different documents about the supply chain of Bangladesh that nearly $66 \%$ of the crop farmers sold their product in nearby weekly markets, and almost $22 \%$ of farmers were involved in selling the products around their local daily markets. This is a common scenario that the small size of the market and carrying process, the underprivileged condition of the different infrastructure, and

\begin{tabular}{lllll}
\hline Issues & Banskhali & Maheskhali & Teknaf & Anwara \\
\hline Main Market & Mia Bazar & Saplapur Bazar & $\begin{array}{l}\text { Teknaf } \\
\text { Chowmuhani }\end{array}$ & $\begin{array}{l}\text { Chatori } \\
\text { Choumuhani }\end{array}$ \\
Buyers & $\begin{array}{l}\text { Households, passing } \\
\text { cargo vessels, local } \\
\text { haats }\end{array}$ & $\begin{array}{l}\text { Households, local } \\
\text { dwellers }\end{array}$ & $\begin{array}{l}\text { Households, local } \\
\text { dwellers }\end{array}$ & $\begin{array}{l}\text { Households, local } \\
\text { dwellers, beparies }\end{array}$ \\
Market & $\begin{array}{l}\text { High unmet local } \\
\text { Opportunity }\end{array}$ & $\begin{array}{l}\text { Unmet local } \\
\text { demand }\end{array}$ & $\begin{array}{l}\text { Linkage to Cox's } \\
\text { Bazar }\end{array}$ & $\begin{array}{l}\text { Linkage to } \\
\text { Chittagong city }\end{array}$
\end{tabular}
Opportunity

Management of agriculture products value chain 
MSCRA

3,2

\section{0}

Figure 3.

Value chain model for vegetable sectors

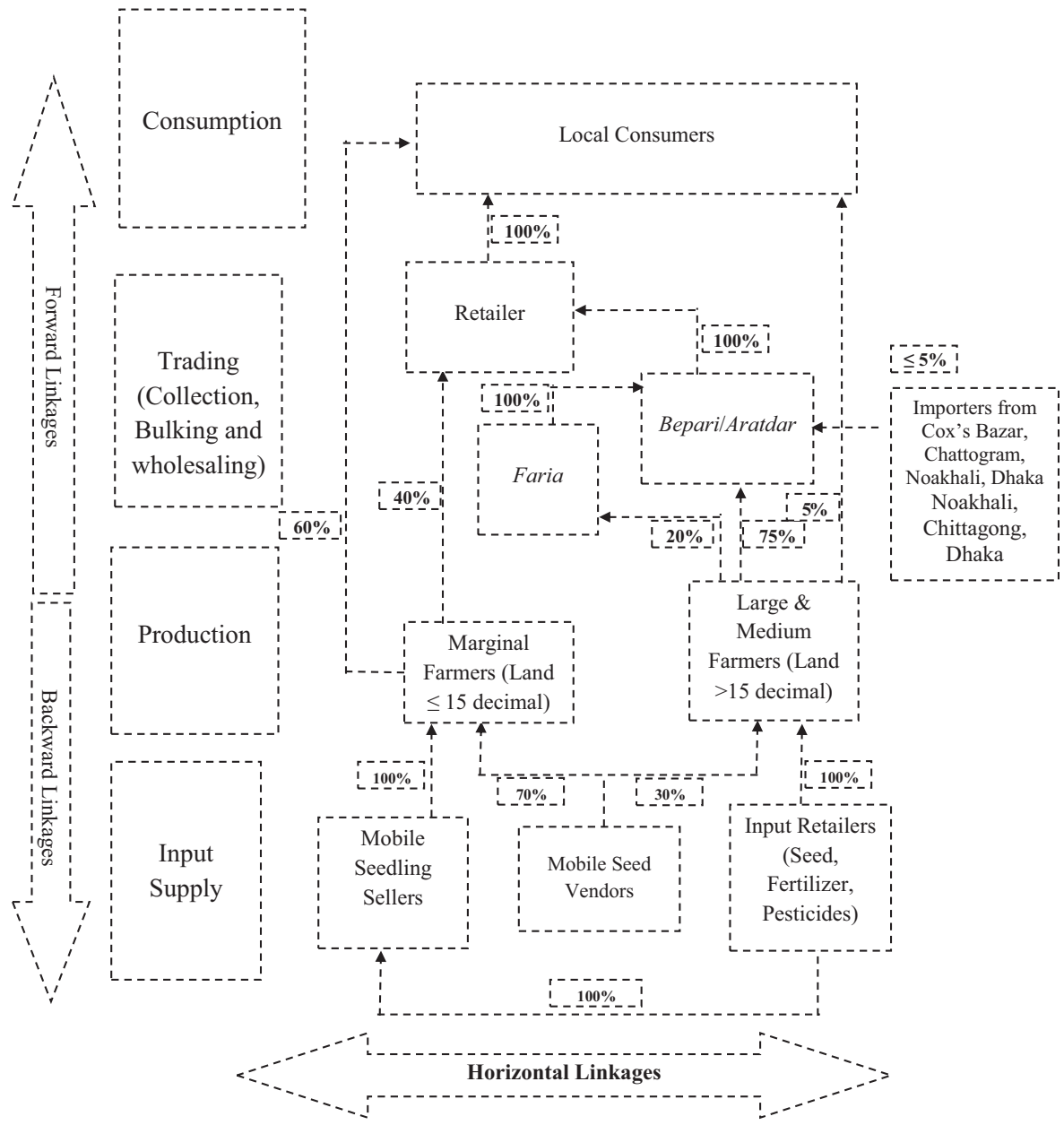

inadequate condition of the storage services strengthen the value instability. Agriculture farmers generally acquire valuable information from various crop farmers, businessmen, traders, broadcasting media and print media (Das and Hanaoka, 2010).

The authors stated that increased vegetable cultivation in these areas would increase the consumption of vegetables of the producers, households and also makes it more accessible for other households to purchase them. The increased supply of vegetables in the study areas will also help decrease the price to some extent, making it more plausible for poor households to afford vegetables more regularly. The SWOT analysis of the vegetable sector value chain is expressed in the following Table 9.

Constraint analysis is recognized as $s$ whatever thing that protects the system from obtaining its ambition. A major constraint in conducting an effective value chain analysis, especially for a new one, is financial constraints for the value chain of vegetables, which encompasses a wide range of events required to bring a product for sale. These include producers, processors, suppliers and customers. A key constraint in managing a successful 
Strengths

(1) Agro inputs like fertilizers, pesticides, seeds (including hybrid) are available

(2) Vegetable cultivation is potentially highly profitable

\section{Weaknesses}

(1) Current productivity is low due to traditional approaches of vegetable cultivation

(2) Farmers believe that saline soil is not appropriate for cultivating vegetables

(3) Lack of awareness about treating salinity in the soil

(4) Limited capital and lack of access to loan, credit

(5) Access to the market is low in terms of physical communication and transportation

(6) Inputs are available, but the quality is not good

\section{Opportunities}

(1) Supply gaps in the local markets for vegetables indicates at least $50 \%$ higher production will be consumed without making a negative impact on the price

(2) At least $50 \%$ of the beneficiaries have a homestead and/or dyke land that can be treated and used for vegetable production

(3) Bulk production in groups will encourage bulk trading and increase the bargaining power of the producers

(4) Input retailers are interested in promoting new products and providing cultivation information to producers

Threats

(1) Lack of traders in the remote areas

(2) The zone is prone to natural disasters like flood, cyclone, and hurricanes
Management of agriculture products value chain

value chain analysis is to possess a detailed analysis of these aspects at a local, regional, national and global level (Table 10).

The authors explored that the main constraints regarding input supply were low input demand, lack of access to farm inputs, and lack of good quality seed. These constraints, on the other hand, offer the opportunity for others such as input fairs, input vouchers, etc. for the development of the input market provision of good quality seed, and input price regulation and control to guarantee fair prices for quality seed. Lack of marketing services such as processing and packaging were also seen as major constraints in the chain. Climate change adaptation strategies arerecommended for vegetable value chain improvement that improves the livelihood of the coastal people. This study offers some intervention options for vegetables for reinforcing to develop the sustainable adaptation options in response to climate change (Table 11).

4.5.2 Value chain analysis for culture fish (tilapia and whitefish). Fisheries and aquaculture make outstanding contributions to food security and livelihood opportunities in Bangladesh. Bangladesh is gifted with enormous marine, brackish, and inland waters enriched with plenty of fisheries resources. The agriculture sector of Bangladesh contributes $14.2 \%$ of GDP, employing $47 \%$ of the effective population, with 17 million people (1.4 million women) relying on the fisheries sector for their livelihoods through aquaculture, fishing, fish handling, marketing, and processing. The agricultural sector has familiar of noteworthy growth over the last couple of decades, with the fisheries sector's subsequent costume. According to the recorded information about the Fisheries Statistics (2015-16) of Bangladesh, the present CAGR for the fisheries sector of the country is about $5.28 \%$ over the last 10 years. According to the present rate of production, fish production of Bangladesh will attain near about 5.05 million metric tons within 2020-21 (Shamsuzzaman et al., 2017). 


\section{MSCRA 3,2}

Public agriculture services

Private agriculture services

Farmers

Financial Services

Infrastructure
Produce vegetables

Providing finances to producers to be used for cultivation of vegetables

Providing information to farmers about cultivation techniques

Providing information to farmers about cultivation techniques and proper usage of inputs

Roads and communication for transportation
Table 10.

Constraints analysis for the vegetable value chain in responses to climate change

\section{Constraints}

They do not source high-quality packaged inputs since the demand for them is low. Also, they are not able to provide the proper information about how these inputs should be used to ensure the best productivity The public extension service is not actively operating in most of the study areas. Thus, farmers are not getting the required information about treating saline soil for vegetable cultivation and using proper cultivation techniques to ensure high productivity. This results in farmers are not being able to produce vegetables or producing poor quality of vegetables and not making much profit from it

The demand for inputs is very low in this area, so private companies are not active in these regions. They are also not conscious of the probability of the cultivable vegetables by treating saline soil, which could be the scope for them to market their products in the study areas. Farmers are currently not aware of how best to use high quality inputs to get the best production from their lands. For marginal farmers, the additional cost of using better inputs is perceived as unnecessary since they are not aware of value addition from higher productivity

Farmers are not aware of the potential to grow vegetables in their land/saline soil, especially about utilizing their homestead and dyke lands. They are also not aware of the profitability of vegetables and of the viability of it being an income-generating activity for them

Currently, they are not well-informed about the cultivation techniques of treating saline soil and also about the best practices to ensure high productivity from vegetable cultivation by using quality inputs Using better inputs for vegetable cultivation will result in some increase in the cost of production. Marginal farmers would be inclined to get microcredit products for investment into vegetable cultivation. But, microcredit institutions do not provide cropbased/seasonal products that can be repaid at the end of a crop cycle

Most of the study areas have poor road connections to urban city of the study areas. Most common types of transportation include low-engine vans, motorcycles, bicycles and trawlers or rowboats for traveling by water 


\begin{tabular}{|c|c|c|}
\hline Actors & Functions & Constraints \\
\hline Rural farias & $\begin{array}{l}\text { Collecting from producers and selling to } \\
\text { Aratdars }\end{array}$ & $\begin{array}{l}\text { Farias are only active for sourcing vegetables } \\
\text { where there is a high production of } \\
\text { vegetables. Even then, most of these regions } \\
\text { have very few producers of good quality and/ } \\
\text { or quantity of vegetables }\end{array}$ \\
\hline Arats or arotdars & $\begin{array}{l}\text { Wholesale facilitation of vegetables at } \\
\text { the main bazaars }\end{array}$ & $\begin{array}{l}\text { Mainly buying from farmers, as well as farias } \\
\text { ability to sell the large quantities. They sell to } \\
\text { local retailers and/or consumers. They are } \\
\text { usually not able to meet the local demand } \\
\text { with the local supply, and then they source } \\
\text { the additional amount required from } \\
\text { aratdars in big city market. }\end{array}$ \\
\hline Rural Retailers & Retailing vegetables to local consumers & $\begin{array}{l}\text { These retailers buy the vegetables from the } \\
\text { arotdars of local farmers, as well as sold them } \\
\text { mainly to local households }\end{array}$ \\
\hline Local consumers & Consumption of vegetables & $\begin{array}{l}\text { Consumption of vegetables is low in these } \\
\text { regions since supply is low and prices are } \\
\text { high. Most producers are able to meet their } \\
\text { household vegetable requirements from their } \\
\text { own homestead gardens }\end{array}$ \\
\hline
\end{tabular}

Management of agriculture products value chain where there is a high production of vegetables. Even then, most of these regions chain have very few producers of good quality and/ or quantity of vegetables ability to sell the large quantities. They sell to local retailers and/or consumers. They are with the local supply, and then they source the additional amount required from aratdars in big city market.

arotdars of local farmers, as well as sold them mainly to local households regions since supply is low and prices are high. Most producers are able to meet their own homestead gardens

Table 10.

Commercially little value of wild fish and freshwater fish culture linger the most widespread fish consumed in the rural areas of the country whereas cultured fish species are significantly increasing at Dhaka, Chittagong and other urban fish markets, along with higher value wild fishes. The studied areas are known for fish production not from culture but from capture, mostly marine and brackish water fish, whereas culturing fishes are traditional and homestead and promoted by the different program. Banskhali, Teknaf and Maheskhali subdistricts also provide a large source of capture fish all over the country and even abroad. Among the culture fishes, the dominating species are mainly tilapia and Indian major carp along with pangasius, shrimp and prawn in few cases. However, the following table (Table 12) shows the fish diversification in these four coastal areas;

A value chain can be comparatively straightforward, for instance, in the case of the fisheries value chain, where rural producers, intermediates and processors/packaging houses, and wholesalers and retailers are involved. A value chain can be extremely complex, for instance, in the case of a passenger car or a personal computer, or in fact in footwear or garments, where producers in various countries across the globe work together. The value chain approaches were taken into account by the funders both as an opportunity and a risk. The risk lies in the fact that developing country producers cannot be integrated into global markets if they cannot meet the requirements of value chains lead firms regarding cost, quality, certification, quantity, and timely delivery. The chance lies in the fact that connecting developing country producers to the world market can be easier if the donor agency manages to build a direct relationship with a value chain lead firm. Generally, proactive responses to climate change are required primarily to respond to three drivers: (1) potential shortages of raw materials; (2) disturbances in manufacturing facilities and distribution systems; and (3) impacts on consumers' purchasing preferences and needs. Generally, adaptive knowledge thinking and actions in response to climate change needed to require across the value chain from the producers to consumers due to all actors in the value chain feel the impact of these drivers. A whole of value chain approach would encourage coordination of activities to mitigate climate risk and minimize the likelihood of maladaptation - those results when 
MSCRA

3,2

\begin{tabular}{|c|c|c|c|c|c|}
\hline Constraint & Intervention & Output & Outcome & Impact & $\begin{array}{l}\text { Potential } \\
\text { partner }\end{array}$ \\
\hline $\begin{array}{l}\text { Vegetable } \\
\text { farmers use } \\
\text { poor quality } \\
\text { inputs }\end{array}$ & $\begin{array}{l}\text { Facilitate the } \\
\text { linkage between } \\
\text { input companies } \\
\text { and input retailers } \\
\text { in these regions to }\end{array}$ & $\begin{array}{l}\text { Input suppliers } \\
\text { will be able to } \\
\text { provide quality } \\
\text { inputs to the } \\
\text { farmers }\end{array}$ & $\begin{array}{l}\text { Farmers are } \\
\text { able to avail } \\
\text { quality } \\
\text { inputs }\end{array}$ & $\begin{array}{l}\text { Farmers are } \\
\text { able to have } \\
\text { higher yield } \\
\text { by at least } \\
20-50 \%\end{array}$ & Input retailers \\
\hline
\end{tabular}

\begin{tabular}{|c|c|c|c|}
\hline \multirow[b]{2}{*}{$\begin{array}{l}\text { Vegetable } \\
\text { farmers follow } \\
\text { traditional } \\
\text { cultivation } \\
\text { practice as they } \\
\text { do not have } \\
\text { access to } \\
\text { information on } \\
\text { improved } \\
\text { practice }\end{array}$} & quality inputs & & \\
\hline & $\begin{array}{l}\text { Create service } \\
\text { provider (seed } \\
\text { retailers) to ensure } \\
\text { information flow to } \\
\text { the vegetable } \\
\text { farmer }\end{array}$ & $\begin{array}{l}\text { Service } \\
\text { providers are } \\
\text { providing } \\
\text { information on } \\
\text { better } \\
\text { cultivation } \\
\text { practices to the } \\
\text { farmers } \\
\text { Farmers are } \\
\text { able to see and } \\
\text { learn about } \\
\text { better } \\
\text { cultivation } \\
\text { practices }\end{array}$ & $\begin{array}{l}\text { Farmers are } \\
\text { using better } \\
\text { cultivation } \\
\text { techniques }\end{array}$ \\
\hline
\end{tabular}

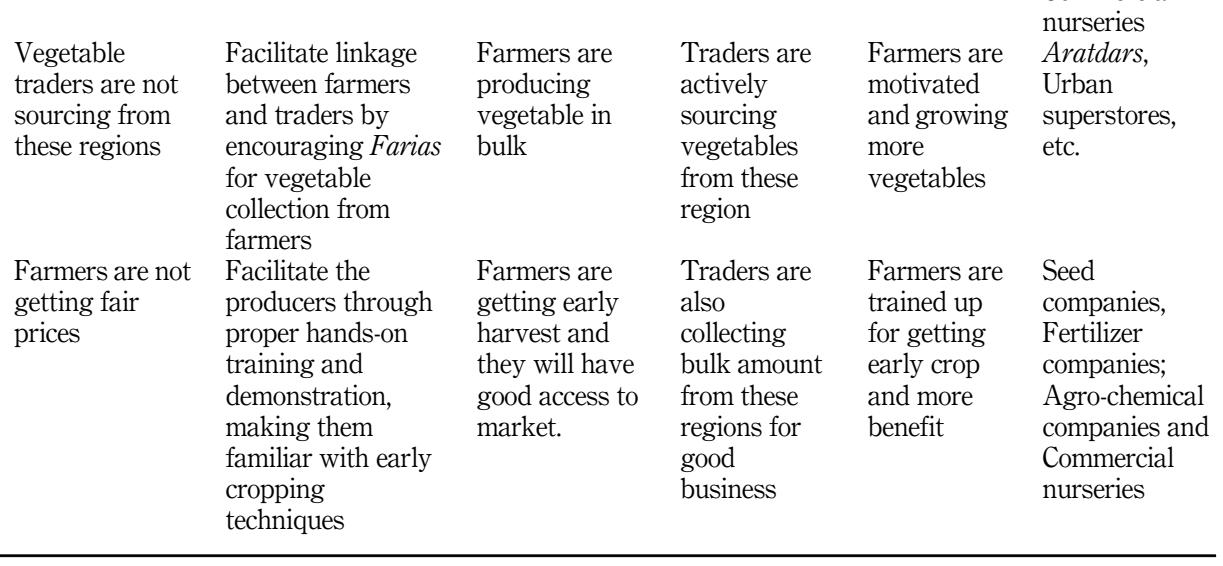

Table 11.

Intervention design table for vegetable as an adaptation of climate change adaptation at precise nodes of a chain in-turn compromise the concert of the value chain as a whole (Lim-Camacho et al., 2015, 2016).

There is a growing demand for tilapia and whitefish both in the local and the national market. The profitable marketing of increasing production of monosex tilapia and other types of tilapia fishes are much superior to traditional fish crops. The differences in the sitewise cost-benefit analysis are shown in the following Table 13:

The fish markets in all the study areas are well developed and linked to the major district markets. Based on the information collected from the project areas, the overview of end markets for tilapias and whitefish can be provided as follows in Table 14:

The majority of the cultured fish production is carried out in big cities; most of the cultivated fish tend to be exported to divisional towns around Bangladesh like Chittagong and Dhaka. Thus, there is a huge potential for supplying more fish from the study areas. Even 


\begin{tabular}{|c|c|c|c|}
\hline Area & Culture fishes & Capture fishes & \\
\hline Banskhali & $\begin{array}{l}\text { Carp (Cyprinus carpio), Rohu fish (Labeo } \\
\text { rohita), Katla fish (Katla katla), Tilapia } \\
\text { (Oreochromis niloticus), Pangas (Pangasius } \\
\text { pangasius), Shimp (Penaeus monodon), Puti } \\
\text { (Putinus sophore) }\end{array}$ & $\begin{array}{l}\text { Hilsha (Hilsha ilisha), Catfish (Arius sona), } \\
\text { Pomfret (Pampus argenteus), Bombay Duck } \\
\text { (Harpadon nehereus), Hair fin anchovy } \\
\text { (Setipina taty), Hard tail scad (Megalaspis } \\
\text { cordyla), Barramundi (Lates calcarifer) }\end{array}$ & $\begin{array}{r}\text { products value } \\
\text { chain }\end{array}$ \\
\hline \multirow[t]{2}{*}{ Maheskhali } & \multirow{2}{*}{$\begin{array}{l}\text { Carp (Cyprinus carpio), Tilapia (Oreochromis } \\
\text { niloticus), Pangas (Pangasius pangasius), } \\
\text { Rohu fish (Labeo rohita), Katla fish (Katla } \\
\text { katla) }\end{array}$} & \multirow{2}{*}{$\begin{array}{l}\text { Hilsha (Hilsha ilisha), Bombay Duck (Harpadon } \\
\text { nehereus), Barramundi (Lates calcarifer), } \\
\text { Shrimp (Metapenaeus monoceros), Gold spot } \\
\text { mullet (Mugil parsia), Pointed tail anchovy } \\
\text { (Coilia dussumieri), Bagrid catfish (Mystus } \\
\text { guilo), Rubicundus eelgoby (Odontamblyopus } \\
\text { rubicundus), Terapon jar (Odontamblyopus } \\
\text { rubicundus), Paradise threadfin (Polynemus } \\
\text { paradiscus) }\end{array}$} & 115 \\
\hline & & & \\
\hline Teknaf & $\begin{array}{l}\text { Carp (Cyprinus carpio), Tilapia (Oreochromis } \\
\text { niloticus), Rohu fish (Labeo rohita), Katla fish } \\
\text { (Katla katla), Puti (Putinus sophore) }\end{array}$ & $\begin{array}{l}\text { Hilsha (Hilsha ilisha), Shrimp (Metapenaeus } \\
\text { monoceros), Rubicundus eelgoby } \\
\text { (Odontamblyopus rubicundus), Paradise } \\
\text { threadfin (Polynemus paradiscus) }\end{array}$ & \\
\hline Anwara & $\begin{array}{l}\text { Carp (Cyprinus carpio), Rohu fish (Labeo } \\
\text { rohita), Katla fish (Katla katla) } \\
\text { Pangas (Pangasius pangasius), Tilapia } \\
\text { (Oreochromis niloticus), Shrimp (Penaeus } \\
\text { monodon) }\end{array}$ & $\begin{array}{l}\text { Barramundi (Lates calcarifer), Bombay Duck } \\
\text { (Harpadon nehereus), Gold spot mullet (Mugil } \\
\text { parsia), Bagrid catfish (Mystus guilo) }\end{array}$ & $\begin{array}{r}\text { Table } 12 . \\
\text { List of common culture } \\
\text { and capture fishes in } \\
\text { the studied areas }\end{array}$ \\
\hline
\end{tabular}

in adjacent local areas of the study areas have fish demand since fish cultivation is not very high in these locations, and the large-size fish, both captured and cultured, tend to be imported out to the study areas and other regions. The market for big-size tilapia and whitefish is growing not only all over Bangladesh, but in these local study areas also. The households have a strong culture of fish consumption, and not just of small-sized fish but also of bigger fish like pangasius, tilapia, carp, etc. There is an overall perception that fish cultivation for commercial purposes cannot be carried out in small ponds.

The fish value chain for four coastal areas was mapped using information from the different project areas. The following value chain map (Figure 4) provides an overview of how the different actors engage in the production, harvesting, processing and selling of tilapia and whitefish in these areas.

In these study areas, there are different types of input suppliers who are active and catering to the different kinds of fish farmers -commercial ones and marginal farmers, for different kinds of needs. Increased homestead cultivation of fish in the study areas will increase the consumption of fish of the producers' households. Increased supply from smallscale producers will also add to more fish being sold at the local bazaar and also make it more accessible for marginal households to purchase them. The SWOT Analysis of the fish sector value chain is expressed in the following Table 15.

From the finding of the study, the authors explored diverse challenges faced by fish farmers, wholesalers and retailers in the fish value chain for climate change vulnerability situation as shown in Table 16.

The value chain for fisheries products elaborates the full variety of actions that are required to carry a product or service from beginning through the different phases of production and delivery to final consumers of fisheries products to the consumer (Porter, 1980; Kaplinsky and Morris, 2000). The study areas are geographically hard to reach areas for marketing of fish is an extremely perishable product and its quality declines very rapidly. 
MSCRA

3,2

116

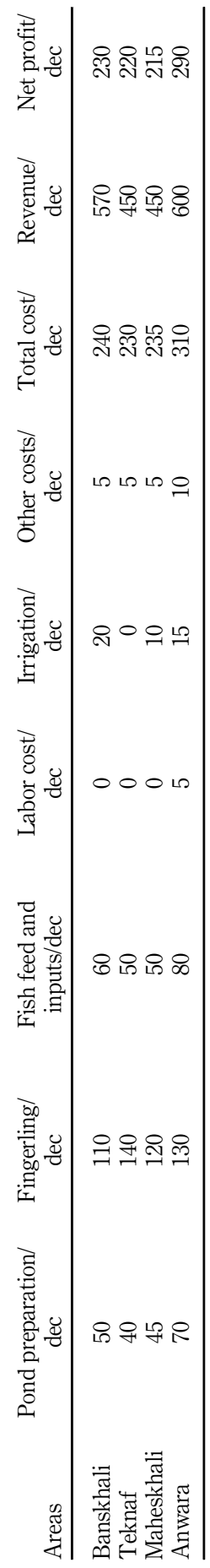

Table 13.

Site specific average cost-benefit for fish culture (BDT)

$(1 \$=78$ BDT $)$ 
Therefore, its quality cannot be reserved unaffected for human ingestion for an extensive time. Consumption and production areas of the study areas are also widely separated. Consumers usually like locally produced carps, shrimp, catfish and other smaller species as commercially important fish. Production of capture and cultured fishes can be enlarged through making finest operation of the existing water resources through a modern and scientific approach of aquaculture and fishing techniques. But the eventual consumers have to rely on an efficient marketing approach to be able to pay for fish at rational prices. Likewise, successful and sustainable aquaculture also relies on an effective allocation system and organization of indigenous knowledge for the study areas.

Coastal people applying indigenous knowledge for quick and immediate value chain approach for better utilization of fish marketing into the local and big market of fisheries product nearby area and urban city. This process helps them for high-income-generating opportunities within a short time against economic losses due to natural disasters and also immediate responses to upcoming natural disasters. Transportation is an elementary utility of making fishing products available improper place and it creates place utility. Coastal people habituated to transport the culture and captured fisheries product in the market through different ways of movements in the commercial places from the producing center (Figure 5).

Farmers are not motivated to use proper inputs for cultivating fish since they are not aware of their higher yield. Thus, there is a potential market for input companies to market and sell their produce to small-scale farmers. The input companies can create linkages with the input retailers who can promote these products in these areas since they have direct contact with the farmers. They also have the motivation to promote better quality inputs to these farmers in order to build better business relationships with them.

Because of being a remote place, there is a lack of opportunities for the establishment of a standard value chain model in these areas. If there is certainty about their crop, farmers will stimulate large-scale fish farming. Apparently, primary fisheries markets should be gratis from the control of arotdars to construct the market spirited so that fishermen could receive a fair price to boost their sales costing revenue. Besides this, the fish landing center with all carrier services will create arat business for the advantage of fish farmers in the long run. The opportunities for working with these constraints can be analyzed to develop intervention plans that can be used as the basis to plan project activities. (Table 17).

\section{Conclusions and recommendations}

The poverty of coastal communities observed in assorted scope in the civilization along with the genesis as per capita income, relative place in society, etc. All experiential confirmation recommended that it is a glitch of the society. It has been defended that no super smack is available for sustainable solutions. But, the authors apparently and inferentially recommended for the implementation of "Value Chain Sustainability" considerably

\begin{tabular}{|c|c|c|c|c|c|}
\hline Issues & Banskhali & Maheskhali & Teknaf & Anwara & \\
\hline Main Market & $\begin{array}{l}\text { Banskhali } \\
\text { municipality, Jaldi }\end{array}$ & Gorakghata & Teknaf municipality & $\begin{array}{l}\text { Chaturi } \\
\text { Choumuhoni }\end{array}$ & \\
\hline Buyers & $\begin{array}{l}\text { Arots, households, } \\
\text { passing ships, local } \\
\text { bazaars }\end{array}$ & $\begin{array}{l}\text { Households, Local } \\
\text { dwellers, moving } \\
\text { hawkers }\end{array}$ & $\begin{array}{l}\text { Households, Local } \\
\text { dwellers, moving } \\
\text { hawkers }\end{array}$ & Traders, households & \\
\hline $\begin{array}{l}\text { Market } \\
\text { Opportunity }\end{array}$ & $\begin{array}{l}\text { High unmet local } \\
\text { demand; demand } \\
\text { from Chittagong and } \\
\text { Dhaka }\end{array}$ & $\begin{array}{l}\text { Potential to export } \\
\text { more to Cox's } \\
\text { Bazar, Chittagong, } \\
\text { Dhaka }\end{array}$ & $\begin{array}{l}\text { High unmet demand } \\
\text { from Cox's Bazar, } \\
\text { Chittagong and } \\
\text { Dhaka }\end{array}$ & $\begin{array}{l}\text { High unmet local } \\
\text { demand; demand } \\
\text { from Chittagong and } \\
\text { Dhaka }\end{array}$ & $\begin{array}{r}\text { Table } 14 . \\
\text { Market analysis for } \\
\text { fish value chain }\end{array}$ \\
\hline
\end{tabular}

Management of agriculture products value chain 


\section{MSCRA \\ 3,2}

\section{8}

Figure 4.

value chain model for fisheries sector in the study areas
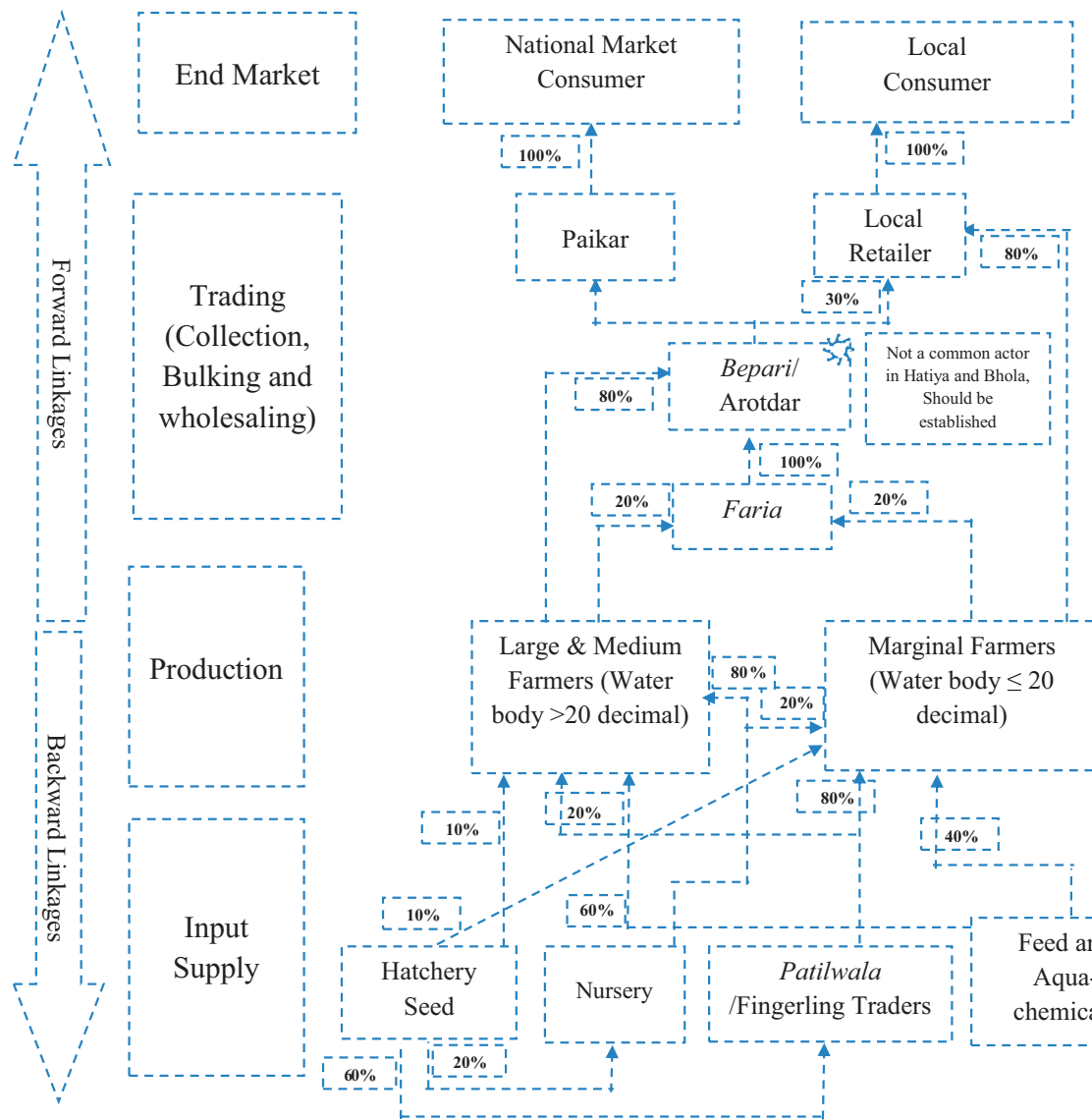

$30 \%$

(Collection,

Bulking and

wholesaling)
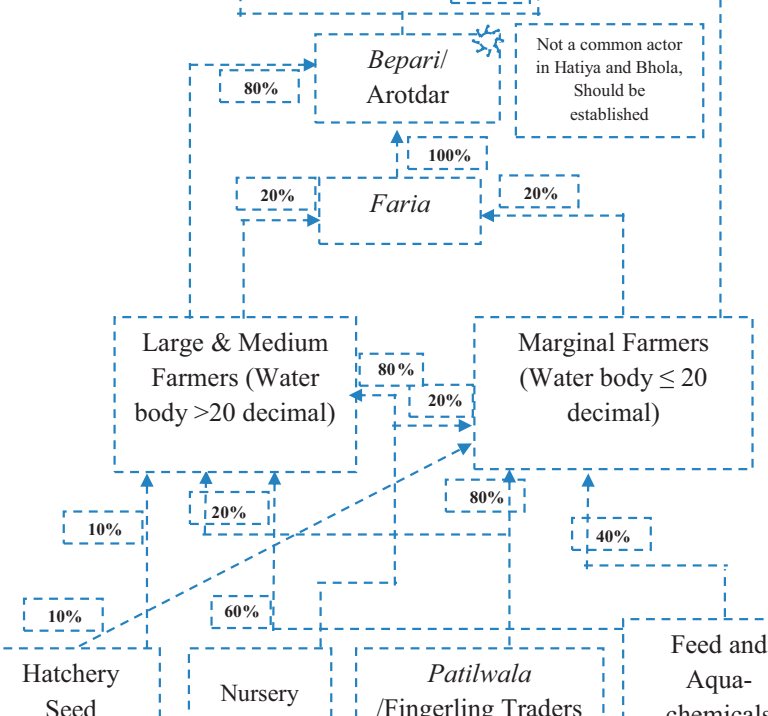

Seed

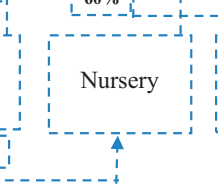

Patilwal

/Fingerling Traders

Feed and

Aqua-

chemicals

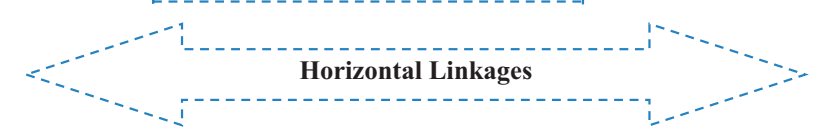

contributed to the solution of this community problem through the transfer or mitigation of poverty from one dimension to another approach. The aim to study, to calculate the contribution of value chain sustainability for the eradication of poverty and adaptation of climate change has been staggered on the noteworthy confirmation in favor to object through enthusiastic methodology in particular sample areas.

Generally, the approach of value chain management requires firms to work jointly to advance coordinated and approachable value-driven processes and approaches and to put forth a widespread effort in sustainable solutions of the market or supply chain problems (Bonney et al., 2007). A sustainable value chain approach in response to climate change effects may therefore exist the occasions for production firms to administer the climate change risk issue by implementing community-based adaptation options for profitable agriculture productions that may be more preferred or conventional by consumers crossways the whole value chain.

The producer and consumer are not getting the full benefit of vegetable and fish prices due to deficient access to market information and undeveloped infrastructure. There are many 
Strengths

(1) Homestead ponds available in at least $60 \%$ beneficiary households

(2) Household ponds can be prepared and managed for fish culture

(3) Almost all beneficiaries have experience in fish cultivation using old techniques

(4) Well established backward and forward linkages in the region

Weaknesses

(1) Lack of knowledge about pond preparation, management and proper techniques for semi-intensive cultivation of fish in small ponds

(2) Misperception about the viability of commercial

fish cultivation in small ponds

(3) Habit of using caught fingerlings or poor quality inputs and habit of growing fish without investing in it

(4) Inputs are not quality-graded

(5) Access to credit and loan is poor

\section{Opportunities}

(1) High local and national demand

(2) Strong linkage with the backward markets of inputs, feeds, aqua chemicals, etc.

(3) Traders and forward market linkages are well established due to the fish market being strong in the study areas

\section{Threats}

(1) Salinity and weather can impact water conditions in ponds

(2) Climatic disaster-prone areas

(3) Limited access to finance for small producers

(4) Dependence on loans limits business decisions and ownership

inferior communication and transport conditions, intermediaries inadequate financial and information service also contributes to the unequal profit margin distribution and a high price of the vegetables. Government involvement, coordination, and monitoring of price fluctuation in the existing value chain are limited. The backward pricing system and market syndicate cause losses for the producer. Understanding the value chain, problem, opportunities, and analysis of the global value chain, we recommended a new value chain approach for vegetable and fish species.

Although climate change adaptation practices of the coastal communities could take place in isolation at specific nodes of the value chain management, there may be greater benefits if all value chain approaches understand by local consumers through responses to and value each adaptation strategy in the local level. This is no different widely acknowledged methods to developing sustainable solutions for the problem of climate change, whereby the participation of society at all scales, including Government, commerce and industry and the wider community, is required (Lorenzoni et al., 2007).

Through justification of the inferential and experiential study, the authors have recommended a specialized model for the abolition of poverty during the value chain sustainability in responses to climate change in the sample areas, established by the following figure. This is verified value chain sustainability with the concept of 3BL themes like Economic performance, Social performance and Environmental performance for eradication of the poverty of climate victims of coastal Bangladesh. The model suggested that performance of ESE performances, as sustainability possibly will play a function in supporting poverty eradication from the society of coastal inhabitants of Bangladesh (Figure 6).

Devastatingly, the respondents of the present study uttered harsh support for farmers of vegetables and aquaculture, fishermen, local fish food production, and local sector-based industries. They also articulated their sustainability for a wide range of adaptation and mitigation strategies by the coastal communities at all levels of the value chain process of 


\section{MSCRA 3,2}

\begin{tabular}{ll}
\hline Actors & Functions \\
\hline Input Suppliers & $\begin{array}{l}\text { Selling fingerlings and fries to the fish } \\
\text { farmers }\end{array}$
\end{tabular}

Selling fish feed, aqua chemicals to the fish farmers

Public agriculture services

Private agriculture services

Farmers

Produce fishes

Financial Services

Providing finances to producers to be used for fish cultivation fish cultivation techniques

Providing information to farmers about cultivation techniques and proper usage of inputs
Constraints

Both good quality and poor quality fingerlings are available in the study areas through different retailers and peddlers. The demand for high-quality fingerlings is low for marginal farmers since perception is that fish cannot be produced for commercial profitability in small ponds

The suppliers have linkage with district-level dealers and are able to provide all necessary products for commercial fish farming. They are not well versed with technical advice about fish cultivation, especially about polyculture in small ponds

Providing information to farmers about The public extension service is not actively operating in most of the study areas. Also, most of their work focused on promoting large-scale fish culture and does not target the marginal farmers

There is a huge demand for fish inputs in the study areas, but there is almost no provision of getting information or technical advice about using them from input suppliers. Private companies can facilitate the information flow by ensuring that information about the use of their inputs is provided by the input suppliers to the farmers

Also, promoting the proper use of inputs to get higher profitability would be a means of marketing for these companies and encourage marginal farmers to move into fish cultivation

Farmers are not aware about the potential profitability in cultivating fish in a semiintensive manner in small homestead ponds. They are also not well-informed about the cultivation techniques to ensure high productivity from fish cultivation by using quality inputs properly

Proper cultivation of fish will require some increase in production cost for pond preparation, feed management, pond management, etc. The need for financial assistance for marginal farmers would occur. But, microcredit institutions do not provide cycle-based/seasonal products that can be repaid at the end of a fish season. This demotivates farmers from using better quality inputs
Table 16.

Constraints analysis for the fish value chain in the study areas 


\begin{tabular}{ll}
\hline Actors & Functions \\
\hline Infrastructure & $\begin{array}{l}\text { Roads and communication for } \\
\text { transportation }\end{array}$ \\
Rural Farias & $\begin{array}{l}\text { Collecting from producers and selling to } \\
\text { Aratdars }\end{array}$
\end{tabular}

Arat (or arotdars) Wholesale facilitation of fish at the main markets

Rural Retailers Retailing fish to local consumers

Local consumers Consumption of fish

\section{Constraints}

Most of the project regions have poor road connections to main bazaar or market. Most common types of transportation include lowengine vans, motorcycles, bicycles and trawlers or row boats for travelling by the river

Farias are highly active in most of the study areas for sourcing fish from medium sized farmers. They will easily start sourcing from smaller farmers if the production increases. Most farias are directly linked to arotdars In Maheskhali and Teknaf subdistricts, there are no established arotdars were seen. Based on production of bulk quantity fish distribution center also can be established in these regions to preserve fishes for best market grabbing. Mainly buying from producers and farias to sell fish in large quantities. They carry out business with both cultivated and captured fish, including marine, brackish water capture fish and culture fishes like tilapia, pangasius, carp, etc. They are directly linked to district markets in Cox's Bazar, Chittagong and Dhaka

These retailers buy the fish from the arotdars, and sell them in small local bazaars. These fish are usually bought by the local households

Consumption of fish is medium in these regions, since supply is low and prices are high. Most producers are able to meet their household fish's requirements from their own homestead ponds
Management of agriculture products value chain 


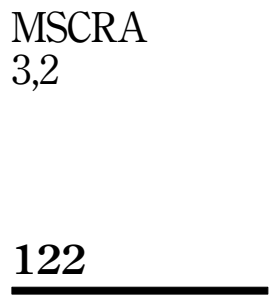

Figure 5.

Flow chart of fish marketing system from landing center to market
Rickshaw/Van: They are habituated three wheel non-mechanized man-driven carrier for transport the products

CNG Taxi/Nasimon/ Tampo/Tamtam: They also used locally made mechanized small lorry/van for fish transport as costing is high

Pickup: Small lorry

Bus: They used Passenger bus for quick and easy transport

Truck: Cargo carrier used for fish marketing in to the long distance market

Pickup/tampo/CNG: These transport using for low cost marketing

Head load: Container carry on head

Rickshaw/Van: Three wheel non-mechanized carrier

Bus: Passenger bus Truck: Cargo carrier

Nasimon: Locally made mechanized small lorry/van

Pickup/tampo/CNG: Small lorry

of the elements recommended for the operationalization of resilience capacity. The paper divulges that, while climate adaptability and collaboration are appropriate rudiments for assessing socio-ecological resilience, suppleness and ingenuity are critical for the analysis of the economic aspects of the climate resilience value chain process for coastal communities. However, adaptability for the climate resilience value chain approach is the fitting constituent decisive a system's aggregate state of the resilience approach for the value chain of vegetables and fishes.

The authors recommended that diversity of institutional conditions of end markets of vegetables and fish species would be required to developed linkages with different categories of harmonization and control of enabling environmental conditions throughout the value chain management. Local, regional, and national networks augment the agricultural crops value chain process in terms of value added, enhancement of the production and harvesting technology, accessibility of the local to the national market and profitable business in the coastal communities. The value chain approach of these vegetables and fish species should be a climateadaptive process and their goal is indispensable to build up thought on learning, funding opportunities, accessibility of commercial markets, sales assurance and quality. All levels of actors and stakeholders involved in the value chain process of vegetables and fish species products should deliberate on competitiveness and efficiency and look for and develop multiple traditions to add value once initial achievement has been obtained with a single deal. The authors proposed that for ensuring sustainability within the agriculture crops value chain, the key imperative features to provide coastal communities for the challenges of food security and changing demands according to the present age. Strong private-sector association along with public-private partnership could gain sustainable agriculture crops based on appropriate value chain development for most vulnerable southeastern coastal communities of Bangladesh. Besides, intensification the poor financial 


\begin{tabular}{|c|c|c|c|c|c|c|}
\hline Constraint & Intervention & Output & Outcome & Impact & $\begin{array}{l}\text { Potential } \\
\text { partner }\end{array}$ & $\begin{array}{l}\text { Management } \\
\text { of agriculture }\end{array}$ \\
\hline $\begin{array}{l}\text { Farmers do not use } \\
\text { quality inputs } \\
\text { (seed, fingerlings, } \\
\text { feed etc.) }\end{array}$ & $\begin{array}{l}\text { Facilitate the } \\
\text { linkage between } \\
\text { input companies and } \\
\text { input retailers in the } \\
\text { study areas to help } \\
\text { them market quality } \\
\text { inputs }\end{array}$ & $\begin{array}{l}\text { Input suppliers } \\
\text { will be able to } \\
\text { provide quality } \\
\text { inputs to the } \\
\text { farmers }\end{array}$ & $\begin{array}{l}\text { Farmers are } \\
\text { able to avail } \\
\text { quality inputs }\end{array}$ & $\begin{array}{l}\text { Farmers are } \\
\text { able to have } \\
\text { higher yield }\end{array}$ & $\begin{array}{l}\text { Hatcheries, } \\
\text { Nurseries, } \\
\text { Feed } \\
\text { companies, } \\
\text { Agro- } \\
\text { chemical } \\
\text { companies }\end{array}$ & $\begin{array}{l}\text { producls value } \\
\text { chain }\end{array}$ \\
\hline \multirow[t]{2}{*}{$\begin{array}{l}\text { Small-scale fish } \\
\text { farmers do not use } \\
\text { proper cultivation } \\
\text { techniques }\end{array}$} & $\begin{array}{l}\text { Create service } \\
\text { providers(input } \\
\text { retailers) to provide } \\
\text { technical advice for } \\
\text { cultivating in small } \\
\text { ponds }\end{array}$ & $\begin{array}{l}\text { Input providers } \\
\text { will be able to } \\
\text { provide technical } \\
\text { advice to the } \\
\text { farmers }\end{array}$ & $\begin{array}{l}\text { Farmers are } \\
\text { using proper } \\
\text { cultivation } \\
\text { techniques }\end{array}$ & & $\begin{array}{l}\text { Hatcheries, } \\
\text { Nurseries, } \\
\text { Feed } \\
\text { companies, } \\
\text { Agro- } \\
\text { chemical } \\
\text { companies }\end{array}$ & \\
\hline & $\begin{array}{l}\text { Provide training and } \\
\text { set up } \\
\text { demonstrations to } \\
\text { showcase better } \\
\text { cultivation practices }\end{array}$ & $\begin{array}{l}\text { Farmers are } \\
\text { knowledgeable } \\
\text { about using } \\
\text { proper cultivation } \\
\text { techniques }\end{array}$ & & & $\begin{array}{l}\text { Hatcheries, } \\
\text { Nurseries, } \\
\text { Feed } \\
\text { companies, } \\
\text { Agro- } \\
\text { chemical } \\
\text { companies }\end{array}$ & \\
\hline $\begin{array}{l}\text { Farmers do not } \\
\text { have access to } \\
\text { finances for } \\
\text { investing in fish } \\
\text { farming }\end{array}$ & $\begin{array}{l}\text { Facilitate linkages } \\
\text { between arotdars/ } \\
\text { financial institutions } \\
\text { and farmers to } \\
\text { encourage financing } \\
\text { options }\end{array}$ & $\begin{array}{l}\text { Farmers are } \\
\text { getting financial } \\
\text { capital to invest in } \\
\text { fish cultivation }\end{array}$ & $\begin{array}{l}\text { Farmers are } \\
\text { using better } \\
\text { inputs and } \\
\text { proper } \\
\text { cultivation } \\
\text { techniques }\end{array}$ & & $\begin{array}{l}\text { Arotdars, } \\
\text { Urban super } \\
\text { stores etc. }\end{array}$ & \\
\hline $\begin{array}{l}\text { Establishment of } \\
\text { fish landing } \\
\text { centers and } \\
\text { support service } \\
\text { providers in } \\
\text { regions like } \\
\text { Maheskhali and } \\
\text { Tekanf }\end{array}$ & $\begin{array}{l}\text { Facilitate farmers } \\
\text { through ensuring } \\
\text { support services }\end{array}$ & $\begin{array}{l}\text { Farmers will be } \\
\text { able to manage } \\
\text { postharvest } \\
\text { procedure } \\
\text { properly }\end{array}$ & $\begin{array}{l}\text { Farmers are } \\
\text { practicing } \\
\text { good post } \\
\text { harvest } \\
\text { technologies }\end{array}$ & $\begin{array}{l}\text { Farmers are } \\
\text { getting } \\
\text { higher yield } \\
\text { for } \\
\text { marketing }\end{array}$ & $\begin{array}{l}\text { Urban ice } \\
\text { factories, } \\
\text { super stores }\end{array}$ & $\begin{array}{r}\text { Table } 17 . \\
\text { Intervention design } \\
\text { table for fish value } \\
\text { chain as an adaptation } \\
\text { to climate change }\end{array}$ \\
\hline
\end{tabular}

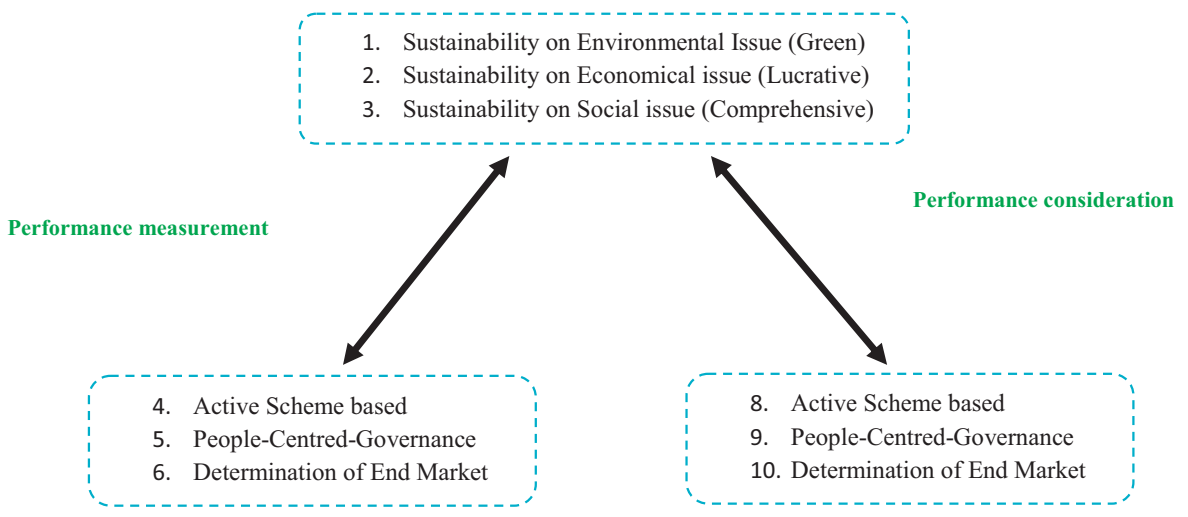

Figure 6.

Sustainability of climate resilience value chain model

(Modification of FAO, 2014) 
MSCRA

3,2 arrangement, focusing on the development of proper financial infrastructure, decreasing power inequity in the local Governance administration and low level of political interference in local community level organizations and recovering the socio-cultural and environmental perspective are the major concerns on the progress of climate-resilient agricultural value chains in Bangladesh.

From the finding of the study, the authors strongly recommended "Value Chain Sustainability" considerably contributed to the resolution of this social problem throughout the transfer of poverty alleviation from one aspect to another. The manuscript projected obliging the theoretical and managerial insinuation of the study with a model titled "Poverty Eradication Model through Sustainability of Value Chain." Through explanation of speculative evidence and present mathematical and qualitative assessment, the authors have been concluded sustainability of the value chain approach through the process of economic, social and environmental sustainability possibly will be hopeful for the abolition of extreme poverty from the society of coastal inhabitants of the south-eastern coast of Bangladesh.

\section{References}

Ahsan, D. and Brandt, U.S. (2015), “Climate change and coastal aquaculture farmers' risk perceptions: experiences from Bangladesh and Denmark", Journal of Environmental Planning and Management, Vol. 58 No. 9, pp. 1649-1665.

Alam, K., Shamsuddoha, M. and Tanner, T. (2016), "The political economy of climate resilient development planning in Bangladesh", IDS Bulletin, Vol. 42 No. 3, pp. 52-61.

Ali, M.Y. and Hossain, M.E. (2019), "Profiling climate smart agriculture for southern coastal region of Bangladesh and its impact on productivity, adaptation and mitigation”, EC Agriculture, Vol. 5 No. 9, pp. 530-544.

Ali, M.M., Shaheed, S.M. and Kubota, D. (1997), "Soil degradation during the period 1967-1995 in Bangladesh : selected chemical characters", Soil Science and Plant Nutrition, Vol. 43 No. 3, pp. 879-890.

Anik, S. and Khan, M. (2012), "Climate change adaptation through local knowledge in the north eastern region of Bangladesh", Mitigation, Adaptation, Strategies and Global Change, Vol. 17 No. 8, pp. 879-896.

Bala, B.K. and Hossain, M.K. (2010), "Food security and ecological footprint of coastal zone of Bangladesh”, Environment, Development and Sustainability, Vol. 12 No. 4, pp. 531-545.

Barua, P. and Rahman, S.H. (2019), "Sustainable value chain approaches for vegetable cultivation in response to climate change: a study in the south-eastern coast of Bangladesh", IUP Journal of Supply Chain Management, Vol. 15 No. 4, pp. 27-40.

Barua, P., Rahman, S.H. and Molla, M.H. (2017), "Sustainable adaptation for resolving climate displacement issues of south eastern Islands in Bangladesh", International Journal of Climate Change Strategies and Management, Vol. 15 No. 2, pp. 60-80.

Barua, P., Rahman, S.H., Rahman, I.K. and Barua, S. (2020), "Climate change and its impact on fishermen community of south-eastern coast of Bangladesh", Water Conservation and Management, Vol. 4 No. 2, pp. 55-75.

BBS (2011), Bangladesh Population Census (2011), Bangladesh Bureau of Statistics, Ministry of Planning, Government of the People's Republic of Bangladesh, Dhaka.

Below, T.B., Mutabazi, K.D., Kirschke, D., Franke, C., Sieber, S., Siebert, R. and Tscherning, K. (2012), "Can farmers' adaptation to climate change be explained by socio-economic household-level variables?”, Global Environmental Change, Vol. 22 No. 1, pp. 223-235.

Bonney, L., Clark, R., Collins, R. and Fearne, A. (2007), "From serendipity to sustainable competitive advantage: insights from Houston's farm and their journey of co-innovation”, International Journal of Supply Chain Management, Vol. 12 No. 3, pp. 395-399. 
Camacho, L.L., Anoma, A., Gemma, K.L., Steven, J.C., Simon, S., Brad, R. and Stuart, M.H. (2015), "Climate adaptation of food value chains: the implications of varying consumer acceptance", Regional Environmental Change, Vol. 70 No. 5, pp. 545-565.

Clarke, D., Williams, S., Jahiruddin, B.K. and Salehinc, M. (2015), "Projections of on-farm salinity in coastal Bangladesh”, Environmental Science Processes and Impacts, Vol. 17 No. 2, pp. 1127-1136.

Cook, M.L. and Iliopoulos, C. (1999), "Beginning to inform theory of the cooperative firm: emergence of the new generation cooperative", The Finnish Journal of Business Economics, Vol. 4 No. 3, pp. 525-535.

Das, R. and Hanaoka, S. (2010), "Perishable Food supply chain constraints in Bangladesh", International Journal of Food Supply Chain, Vol. 5 No. 2, pp. 13-29.

Dekens, J. and Fredrick, B. (2014), "Promoting an integrated approach to climate adaptation: lessons from the coffee value chain in Uganda”, Supply Chain Management, Vol. 5 No. 2, pp. 55-65.

FAO (2014), Developing Sustainable Food Value Chains - Guiding Principles, Rome, Food and Agriculture Organization.

Fraser, E., Dougill, C.H., Hubacek, C.H., Quinn, J.K., Sendzimir, M.L. and Termansen, T. (2011), "Assessing vulnerability to climate change in dryland livelihood systems: conceptual challenges and interdisciplinary solutions”, Ecological Sociobiology, Vol. 16 No. 1, pp. 33-42.

Füssel, H.M. (2010), "Review and quantitative analysis of indices of climate change exposure, adaptive capacity, sensitivity, and impacts”, Global Environmental Management, Vol. 20 No. 5 , pp. 70-90.

Hasan, S.S., Sultana, S., Khalil, M.I. and Mazumder, M.D.H. (2009), "Identification and use of indigenous technologies (ITs) by the farmers in fisheries and livestock components", Bangladesh Research Publication Journal, Vol. 2 No. 1, pp. 351-360.

Hasan, S.S., Ashek, M., Mithun, K.G. and Khalil, M.I. (2017), “Assessing of farmers' opinion towards floating agriculture as a means of cleaner production: a case of Barisal district, Bangladesh", British Journal of Applied Science and Technology, Vol. 20 No. 6, pp. 1-14.

Hooq, M.S., Raha, S.K. and Sultana, N. (2012), "Value addition in vegetables production, processing and export from Bangladesh", Bangladesh Journal of Agricultural Research, Vol. 37 No. 3, pp. $377-388$.

Hossain, M.I. (2001), “A macro model for Bangladesh. Micro impacts of macroeconomic and adjustment policies in Bangladesh”, Working Paper No. 3, Bangladesh Institute of Development Studies, Dhaka.

Islam, M.S. (2003), "Perspectives of the coastal and marine fisheries of the Bay of Bengal, Bangladesh", Ocean and Coastal Management, Vol. 15 No. 2, pp. 35-50.

Islam, N. (2014), An Introduction to Research Methodology, 3rd ed., University Press, Dhaka.

Jacinto, E.R. (2004), A Research Framework on Value Chain Analysis in Small-Scale Fisheries, Tambuyog Development Center, Philippines.

Kaplinsky, R. and Morris, M. (2000), A Hand Book for Value Chain Research, International Development Research Center (IDRC), Ottawa.

Lim-Camacho, Ariyawardana, A., Crimp, S.J., Somogyi, S., Ridoutt, B. and Howden, S.M. (2015), "Facing the wave of change: stakeholder perspectives on climate adaptation for Australian seafood supply chains", Regional Environmental Change, Vol. 15 No. 4, pp. 595-606.

Lim-Camacho, Ariyawardana, A., Crimp, S.J., Somogyi, S., Ridoutt, B. and Howden, S.M. (2016), "Climate adaptation of food value chains: the implications of varying consumer acceptance", Regional Environmental Change, Vol. 16 No. 2, pp. 580-600.

Lorenzoni, I., Nicholson-Cole, S. and Whitmarsh, L. (2007), "Barriers perceived to engaging with climate change among the UK public and their policy implications", Global Environmental Change, Vol. 17 No. 4, pp. 445-459.
Management of agriculture products value chain

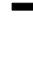


MSCRA

3,2

Lusine, H., Alfons, G.J.M., Jack, G.A.J. and Olafvan, K. (2007), "Performance measurement in agrifood supply chains: a case study”, Supply Chain Management: An International Journal, Vol. 12 No. 4, pp. 304-315.

Mahashin, R. and Roy, R. (2017), "Mapping practices and technologies of climate-smart agriculture in Bangladesh", Journal of Environmental Science and Natural Resources, Vol. 10 No. 2, pp. 29-37.

Miller, C. and da Silva, C. (2007), "Value chain financing in agriculture", Enterprise Development and Microfinance, Vol. 13 No. 2, pp. 95-108.

O'Brien, K. (2010), "Responding to climate change: the need for an integral approach", Integral Institute Journal, Vol. 4 No. 2, pp. 1-12.

Porter, M.E. (1980), Value Chain Analysis, Oxford Press, London.

Rahman, S. and Parkinson, R.J. (2007), "Soil fertility and productivity relationships in rice production system, Bangladesh", Agricultural Systems, Vol. 92 No. 5, pp. 318-333.

Rahman, M.R., Kazuo, A. and Shinya, T. (2014), "Development of shrimp-based cropping systems in the coastal area of Bangladesh: a village-level study in Satkhira district", Journal of Land Use Science, Vol. 9 No. 2, pp. 195-210.

Regmi, B.R. and Bhandari, D. (2013), "Climate change adaptation in Nepal: exploring ways to overcome the barriers", Journal for Livelihood, Vol. 11 No. 1, pp. 43-61.

Shamsuzzaman, S.M., Islam, M.M., Tania, N.J., Mamun, A.K., Barman, P.P. and Xu, S.X.K. (2017), "Fisheries resources of Bangladesh: present status and future direction", Aquaculture and Fisheries, Vol. 2 No. 4, pp. 145-165.

Shelley, I.J., Misuzu, T.N., Nakata, N.M., Haque, M.S. and Yoshiaki, I. (2014), "Rice cultivation in Bangladesh: present scenario, problems, and prospects", Journal of International Cooperative Agriculture Development, Vol. 14 No. 2, pp. 20-29.

Singh, U.S. and Mishra, U.S. (2013), "Vegetable supply chain: a conceptual study", Food Science and Quality Management, Vol. 15 No. 3, pp. 45-50.

Trienekens, J.H. (2011), “Agricultural value chains in developing countries: a framework for analysis”, International Food and Agribusiness Management Review, Vol. 14 No. 2, pp. 51-82.

Uddin, B. and Akhter, B. (2019), "Antecedents and outcomes of supply chain management in Bangladesh”, Modern Supply Chain Research and Applications Vol. 1 No. 1, pp. 68-87.

Zahangeer, M.A., Boggs, C.J., Mitra, S., Haque, M.J., Halsey, J.M., Rokonuzzaman, R.M., Saha, S. and Moniruzzaman, M. (2017), "Effect of salinity intrusion on food crops, livestock, and fish species at Kalapara coastal belt in Bangladesh”, Journal of Food Quality, Vol. 10 No. 2, pp. 1-25.

\section{Corresponding author}

Prabal Barua can be contacted at: prabalims@gmail.com

For instructions on how to order reprints of this article, please visit our website:

www.emeraldgrouppublishing.com/licensing/reprints.htm

Or contact us for further details: permissions@emeraldinsight.com 